\title{
Redefining the reference librarian in the university environment
}

\author{
Lenuța Ursachi \\ Faculty of Letters, University of Bucharest \\ E-mail lenuta.stratu@drd.unibuc.ro.
}

The reference librarian and the services provided hold more than ever the attention of users at the "Dunărea de Jos" University Library of Galati (DJULG). The Internet, technology and struggle for survival left a significant mark on both librarians' skills and reference services in the new context of the information society. In order to align with new trends in librarianship and to respond effectively to the increasingly complex demands of users, the reference librarians had to move beyond the traditional and reinvent themselves. As a result, new skills have been acquired and new services emerged in the information landscape of the university library.

The paper examines the evolution of the reference services at DJULG over the last ten years, emphasizing the changes of the librarian profile in this area. The variety of information sources, the emergence of new information technologies, the movement on open access have been the main elements that contributed to the professional development of the reference librarian and the implementation of new models of services for users. The case of the university library in this study reveals different profiles of the reference librarian: researcher, educator in information literacy, bibliometrician, wikilibrarian, digital resources manager, reference manager etc. Not far from the truth, we can say that the reference librarian became a chameleon, from the perspective of information evolution and ensuring sustainable library services.

Keywords: reference librarian, digital services, academic libraries, library marketing, Romania

\section{Introduction}

The information has developed and diversified within an online environment which seems to be the number one friend of nowadays user. Researching a particular issue no longer depends on visiting the library, consulting catalogs, approaching the librarian or writing references collected down on the paper. The use of online library catalogs, mobile access to subscribed databases, open access to scientific information could be the reasons why the physical contact with the library was gradually replaced by the virtual one. Two questions arise here: can the online environment completely replace a library and is the opinion of a librarian still necessary? Undoubtedly, the library work environment has changed continuously, and the emergence of new information technologies is inevitable. Consequently, the reference work must be constantly rethought because the librarian's professional life will be engaged in a permanent competition.

The paper examines the evolution of the reference services at the "Dunărea de Jos" University Library of Galați (DJULG) in the last ten years, emphasizing the profile changes of the librarian in this area. The variety of information sources, the emergence of new information technologies, the movement on open access to information have been the main components that contributed to the professional development of the reference librarian and the implementation of new models of services for users. The case of the university library in this study presents to the readers a chameleon reference librarian: researcher, educator, bibliometrician, wikilibrarian, digital resources manager, reference manager etc. 


\section{Literature review}

Danner (1998) reviews the professional categories that handle information, including accountants, archivers, librarians, data administrators, information systems analysts, museographers, publishers, computer scientists. They are considered mediators because they use the right resources, which are delivered at the right time, in the most appropriate form so that they can be used at a cost that justifies the value of the communicated information. According to Danner (1998) what distinguishes the librarian from the other categories are the following characteristics:

the quality of information is a top priority;

the activities carried out are focused on content;

the user is guided to find out how the information is searched and where it is located.

In a similar way, in the chapter Radiography of a profession, the authors define the documentarian as the specialist in information processing, mediator and communicator (Buluță et al 2007 p. 105). The increase and diversification of the library fund indicated, at least in the first phase, some weaknesses of the librarian in terms of access to information content. She/he has to know how to select the most valuable information, from a wide typology of resources, to meet the expected needs of the user (Horvat 1996 p. 177). To do that, the librarian must know very well the collections of the library and be a good specialist in the field.

The emergence of new information technologies placed the librarian in a position to lose control over her/his qualification, in a sense that traditional skills were no longer enough in relation to the increasingly complex requirements of users. And if the work of a librarian depends on information technology, then her/his skills need to be improved in this direction. The literature pointed out two categories of librarians' skills: professional and personal. The professional skills refer to the understanding of information sources content or a particular topic of interest to the organization or user, how to use the right technology to obtain the information, how to manage, evaluate and deliver it or how to conduct an effective research. When speaking of the personal skills, we mean the commitment to provide excellent services, the interest to discover new challenges and opportunities related to the profession, effective communication skills, teamwork both as a leader and as a member, flexibility, etc. (Danner 1998).

The reference librarians (RL) are metaphorically called defined by Anghelescu (2008) as the showcase of the institution, being the first people users meet when they enter the library. The technologies provide new ways of searching and organizing information and certainly influence the reference work. Thus, a certain degree of emphasis should be put on learning and understanding them. In the past, the traditional library catalog, a flexible and incredibly versatile tool for researchers, was very important to the RL, perceived in those days as an information keeper or index creator. Once information abounded on the market, search and retrieval tools became very important, transforming RL into a technology expert. Goetsch (2008) and Coravu (2012 p. 62) draw the attention to the characteristics of RL and the necessary skills found on the recruitment pages of USA university libraries in the period 1995-2005:

- 1997 - the appearance of the Internet Explorer browser - the reference staff must have knowledge on the use of the Internet; the advertised positions referred to: the librarian responsible for electronic services, the librarian of electronic references, the librarian responsible for accessing databases or the reference librarian for network resources; the skills needed were related to online search and supporting users in this matter, use of printed or electronic resources, experience in computer applications (operating systems, software packages);

- 2000 - the appearance of the Google search engine - the advertised positions referred to: the librarian responsible for electronic/digital resources or services, the librarian of web services, the specialist interface librarian, the instructor librarian, etc.; the necessary competencies involved knowledge of electronic resources, applications and web development, personal training, use of statistics, web publishing, training sessions based on web technology; at that time, RLs used various web applications to provide virtual assistance to users such as e-mail, chat or instant messaging; 
- 2005 - digital becomes the watchword, the mediated positions listed the digital applications and system librarian, digital initiatives librarian or the librarian responsible for electronic training of users; competencies were associated with technical services rather than reference services.

As Coravu (2012 p. 63) argued we won't meet such library positions in Romania. Therefore we can appreciate that the classification of library profession in Romania is dry when we refer to librarian, bibliographer, documentarian, researcher, system analyst etc. The reference librarian is not found in Romanian nomenclature, being more a term adopted from USA, associated with the type of services provided. The emergence of new information technologies and the abundance of information on various media, make their mark on the activity of RL. Anghelescu (2008) stated that RLs moved away [from] their work with the book and reformed the reference area by giving up traditional activities and penetrating the digital sphere.

\section{RL profile at DJULG during 2010-2020}

\subsection{The evolution of RL responsibilities and bibliographic activity}

The Reference and Bibliographic Research Department of DJULG has gone through some changes in terms of its name: the Bibliographic Information Department (1996), the Bibliographic Information and Documentation Department (2003) and the Reference and Bibliographic Research Department (2008-onwards). Since 1997, the team of this department consisted only in one librarian with higher education who was processing the complex inquiries. Article 16 of the Regulations on organizing and functioning of the DJULG (ROF) approved in 2003 mentioned the bibliographic and information tools developed at that time by the Bibliographic Information and Documentation Department (Biblioteca Universității "Dunărea de Jos” din Galați 2003):

- Bibliographic bulletin (list of new books entered in the library collections) - edited four times a year;

- $\quad$ Repertory of periodicals entered in the library collections - with annual frequency;

- Repertory of doctoral theses supervised by professors affiliated at DJUG - with annual frequency;

- $\quad$ Library guide - occasionally published.

The ROF revised in 2008 included five articles to the activity carried out by RL within the Reference and Bibliographic Research Department. The activities performed were also mentioned in the job description (Biblioteca Universității "Dunărea de Jos" din Galați 2008):

- $\quad$ orienting and informing the user about collections, services, tools and management of the library;

- $\quad$ bibliographic information and users' interests regarding the purchase of publications;

- $\quad$ editing of bibliographic materials (bulletins, repertories) in printed and electronic format;

- $\quad$ development of library marketing tools (guides, brochures, flyers)

- $\quad$ providing specific references in person or electronically (by e-mail);

- $\quad$ conducting the reference interview and solving the bibliographic research inquiries;

- $\quad$ updating the library web page in terms of library collections and events;

- $\quad$ creating new information tools for users;

- $\quad$ providing statistical data related to the reference area;

- $\quad$ reporting inaccuracies found in the integrated library software.

The tools developed within the Reference Departament included two additional bibliographic materials: Bibliography of reference works entered in the library collections (occasionally) and Bibliography of Shakespeare publications entered in the library collections (occasionally). The year of 2019 brought to DJULG new regulations and two work procedures related to the reference position: Providing references and Developing information tools. The work procedures defined specific terminology and legislation, described the procedure itself (documents used, material resources, work stages), how the results are capitalized, what are the responsibilities of the RL and the types of documents used. Supplementary activities can be distinguished here:

- development of the digital institutional repository;

- $\quad$ administration of the library Facebook page;

- $\quad$ posting news on the library website;

- $\quad$ training sessions with library users. 
During the period of 2010-2020 there have been major changes in the reference activity mainly due to the impact of information technologies. At this moment, bibliographic bulletins are no longer printed, but they are available online, in the form of lists accessed via the online library catalog (OPAC). The bibliographies on specific topics are currently stored in digital format, being available through two important tools: digital repository and Microsoft Teams. Microsoft Teams has been adopted this year, once the COVID-19 pandemic had spread around the world. It becomes an essential tool for referencing, organizing training sessions or meetings and delivering electronic documents. Figure 1 shows how the requests made by library users are managed. They are grouped on different channels representing the university faculties. The RLs upload bibliographies and electronic documents in folders named by the topics investigated.

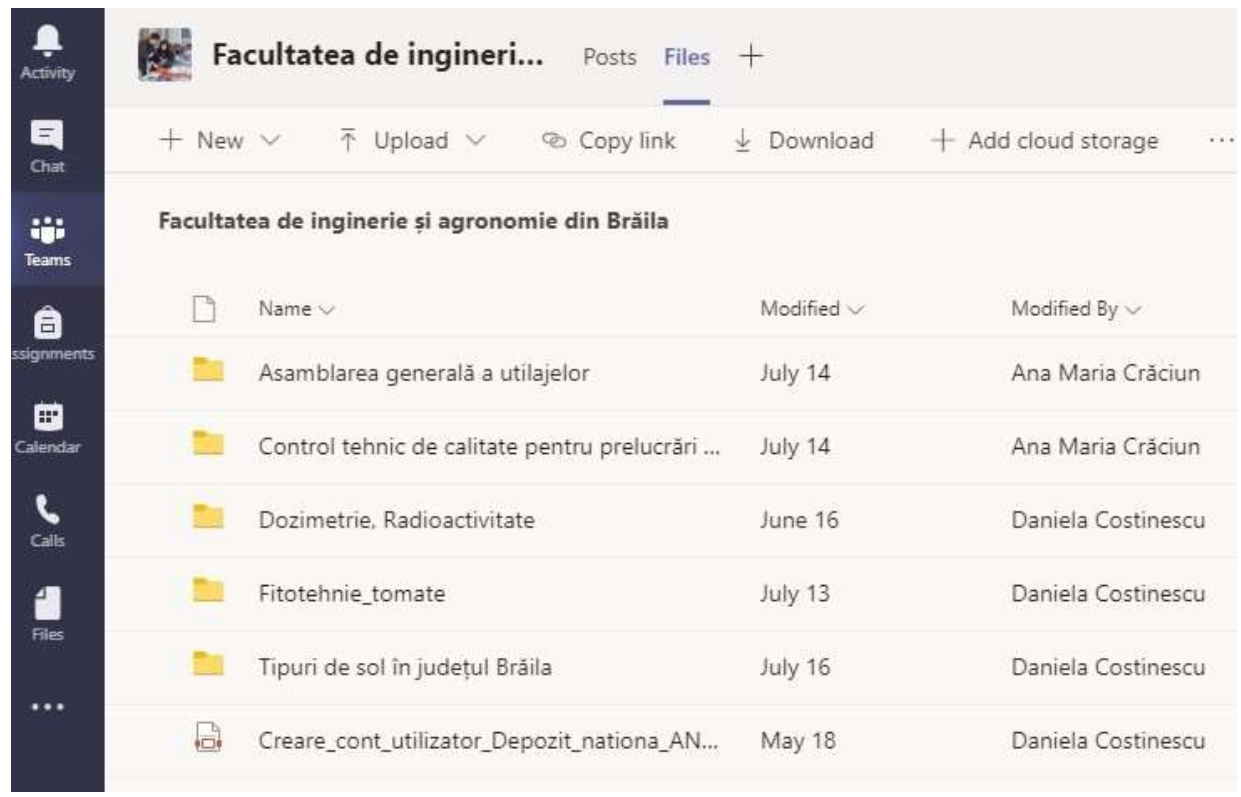

Figure 1. Bibliographies storage on Teams platform at DJULG

\subsection{The reference librarian as researcher}

The scientific research results have been published by the RLs from DJULG since 2010. Horvat Săluc (1996 p. 178) acknowledged that a librarian should conduct research and contribute to the enrichment of the library science. The topics discussed within the meetings of Reference Section and Information Literacy Section of the Romanian Librarians Association (ABR) have been always inspirational to the library community. The research activity at DJULG has been mainly focused on the following subjects, some of them being also disseminated at national and international events:

the world of the university librarian;

information literacy;

video tutorials;

citation models;

reference managers.

Besides published results, other topics have been studied during the analyzed period due to some internal projects, most of them being with reference to the information technology (integrated content management solutions, screenrecording software etc.).

\subsection{The reference librarian as educator in information literacy}

In 2012, the first set of information literacy tutorials in Romanian was published on a social media platform. Slideshare has been the chosen platform for instant publishing. The tutorials referred to the information sources used in research process, searching and locating information, citing information sources, creating the bibliography, etc. In the same year, a new form of collaboration with the faculties began to emerge. A set of seminars with a group of master students from the Faculty of Food Science and Engineering was organized. The focus was on information retrieval systems and ethical use of information. 
Subsequently, meetings with teachers, students and doctoral students followed and the area of debates was extended on other issues such as open access to information and remote navigation in databases, copyright issues, publishing alternatives and management of references. The opening academic year of 2016-2017 or 2017-2018 represented a special opportunity for RL to speak to groups of students from the Faculty of Legal, Social and Political Sciences. They were introduced in the process of searching and retrieving information through Koha library catalog, online databases and reference management. Similar seminars followed in 2019 and 2020 with master students from Faculty of Automatics, Computer Science, Electronics and Electrical Engineering. The meetings organized in 2020 took place on Microsoft Teams platform, due to COVID-19 pandemic.

\subsection{The reference librarian as reference manager}

Promoted since the end of 2013, the management of bibliographic references through software tools is still a topic accepted with some reservations by the academic community at DJUG. RL studied Mendeley, Zotero and EndNote and published a series of online guides in text and video format. Individual and group training sessions have been organized in the library as well as in faculty spaces since 2013. The paper The Reference librarian Face-to-Face with Reference Management (Ursachi 2018) described scenarios met during some of the reference interviews:

How can I organize different types of resources for my article?

How can I make a list of my papers indexed in Scopus or Web of Science?

How can I use a certain citation style for my article?

As team member in PERFORM project, RL had the position of short-term expert. Three meetings had been planned during the period April 2015-June 2015 aimed to develop the digital skills of the targeted audience consisted of doctoral and postdoctoral students. How to choose a citation manager (Mendeley, Zotero or EndNote online), online tools for digital researcher profile and bibliometric analysis in major databases were the main activities incorporated on the agenda of these meetings (Ursachi 2017).

Similar experiences took place in two different projects financed from innovation and development funds (FDI) in 2019 and 2020. Within these experiences, the RL was found in the position of educational expert. The refresher course on bibliographic references management organized by the Department of Continuing Education and Technology Transfer of DJUG in 2019 continued also in 2020. They facilitated the participation of academics and $\mathrm{PhD}$ students with the purpose to review their information and learn new skills needed for their profession. The meetings have been interactive and very constructive. The agenda covered information sources provided by the library, reference managers (Mendeley, Zotero, EndNote online) and Publish or Perish bibliometric tool. Unlike 2019, the course planned in 2020 took place in the online environment, through Microsoft Teams platform. In both cases, all participants created accounts on Mendeley and Zotero and joined the working groups created by the RL on each software website. For the final evaluation, the participants wrote a short text following the steps (Fig. 2):

- $\quad$ select one of the two softwares, Mendeley or Zotero;

- $\quad$ choose a citation style which fits to their field of interest or journal;

- $\quad$ create a folder within the working group of the software they choose to work with;

- $\quad$ search and save five references in their folders (the types of documents covered are: book, book chapter, journal article, conference proceeding and website);

- $\quad$ insert the citations in Word document and automatically create the bibliography. 


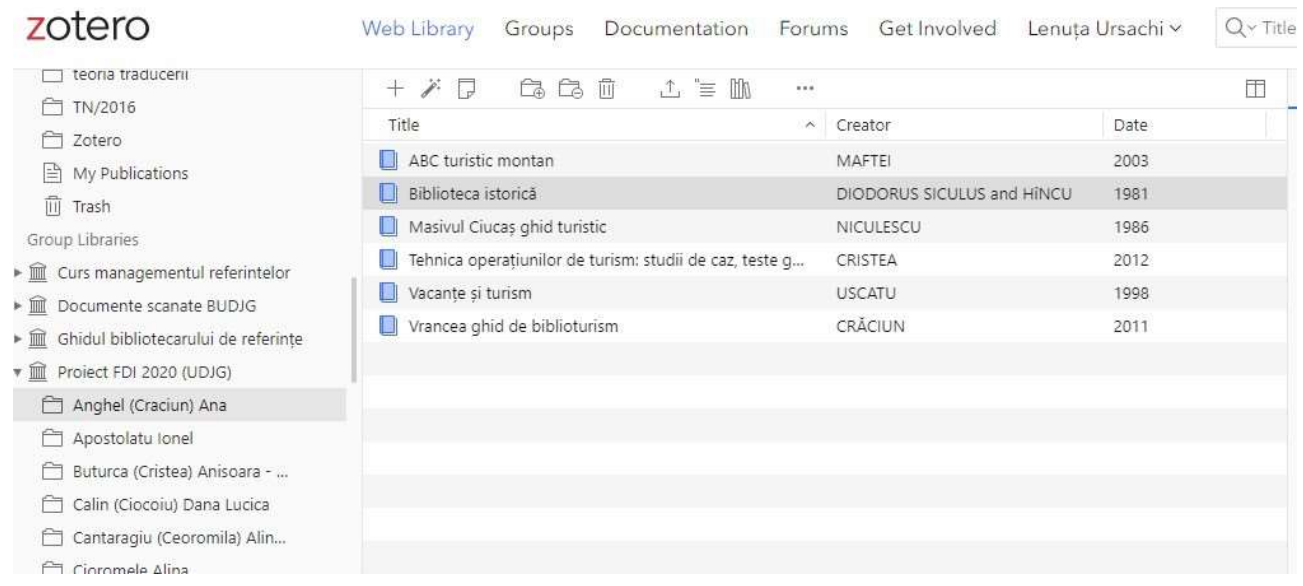

Figure 2. The working group of 2020 FDI project in Zotero

These courses were considered successful and here are some comments sent by the participants:

"I really enjoyed the course. Very well structured with up-to-date information. If you have more classes, I would love to participate. "

"New and valuable information".

"Repeated thanks for the enlightenment".

"Congratulations for the supporting and substantiating course."

"Thank you very much for the information provided, they are very helpful!"

"Thank you for your time and for everything we have learned from you!"

"Thank you for the information provided during the course and being available in the future!"

"Thanks for the information and knowledge you shared!".

\subsection{The reference librarian as digital services librarian}

The project regarding the new website of the library is based on the collaboration between the RL and IT member. The design solution and the main menus have been the RL's proposal. The IT member installed the software application and designed the main page. In addition, an administrator account has been created for the RL. The development of digital skills on editing in Joomla has resulted. Consequently, more than 200 web pages have beend designed, in a different manner than those included in the previous website version of 2012. Launched in August 2020, the new library website incorporated many elements focused on resources and scientific research: searching, evaluating and citing information, copyright and plagiarism, publishing of research results, digital services, etc. For the first time, three sets of webpages have been developed to promote reference managers through the website of DJULG (Fig. 3).

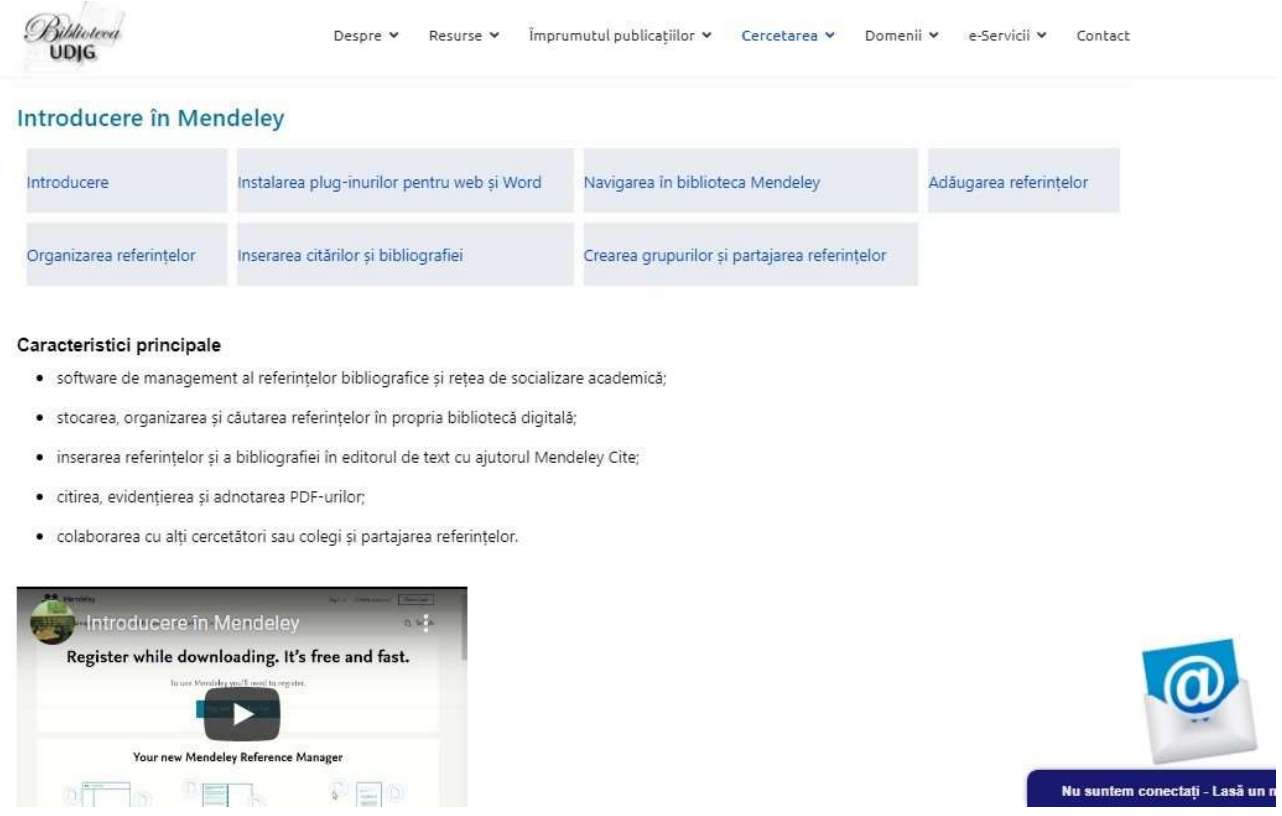

Figure 3. Mendeley presence on DJULG's website 
As mentioned before, the information has been edited in Joomla, both in "visual" mode and source code. Editing in "visual" mode is quite like in any text editor. The RL experienced editing in the source code in order to integrate the video guides published on YouTube (embed), use color CSS codes and a menu navigation. Each set of pages used the same pattern (with a small difference for EndNote online). It referred to the working steps with these softwares: account creation and software download, browsing the digital library, adding references, organizing references, inserting citations and bibliography and creating groups and sharing references.

The implementation of the Google Custom Search Engine (GCSE) service in 2017 was the consequence of the RL's participation at a webinar supported by the director of the National Science Library of Georgia. In order to put in practice the acquired knowledge, the search engine was set up by using the Google library account. GCSE has been built for multiple searches in Koha catalog, ARTHRA digital repository and library website. Subsequently, the source code provided was integrated within the homepage of library website.

The implementation of Koha in 2016 was an internal project of DJULG. The RL played a key role in the study of the MARC21 bibliographic format, the preparation of Koha user manual and the creation of video tutorials on Koha. The integration in 2018 of the library video guides in OPAC was another element of novelty for DJULG and the action was aiming to deliver remote services directly from the online catalog.

The development of the hosting platform for the scientific journals of DJUG and the implementation of the UGAL Index portal are other successful projects finished in 2019. The RL contributed to the creation of three journal websites by using Open Journal System and the library guide on how to navigate UGAL Index portal. The training session brought together the RL, academics and doctoral students from DJUG. Live demonstrations revealed to the audience the basic functions of the portal: simple, advanced and faceted search, browsing and results saving.

The digital reference services included social networks to keep a close contact with library users. LinkedIn, academia.edu, ResearchGate have been selected for the sharing of educational content. Moreover, the library's Facebook page was considered to be the perfect tool to promote events organized by the library and university, to share useful news from database providers or library catalog, etc. (Ursachi \& Scutelnicu 2012).

\subsection{The reference librarian as repository manager}

The implementation in 2011 of the ARTHRA institutional digital repository had a strong impact on the RL's activity. For the testing phase of the software, ARTHRA was chosen as the right tool for the electronic archiving of bibliographies. Later, library guides and statistics as well as librarians' articles and presentations have been included in ARTHRA. At this moment, the timplementation of DSpace-CRIS is ongoing. Besides research outputs, the new digital repository will manage researcher profiles (Fig. 4), organizations, projects and other entities (journals or events).

\subsection{The reference librarian as bibliometrician}

Cox, Gad \& Petersohn (2017) stated that bibliometrics is a subdiscipline of library and information science which aims to evaluate scientific research by using indicators and tools. The RLs deal with a proliferation of publication metrics which attempt to measure research at different levels: articles, journals, individuals, organizations, countries. The experience of using complex databases, knowledge of the indicators used in bibliometrics and altmetrics, the ability to share results of analysis in citation trends, alternative metrics, collaboration profiles are some of the main skills mentioned for the advertised jobs in higher education. Elizabeth Gadd (2017) underlined the importance of a good collaboration between library and research/planning office for the benefit of the institution. 


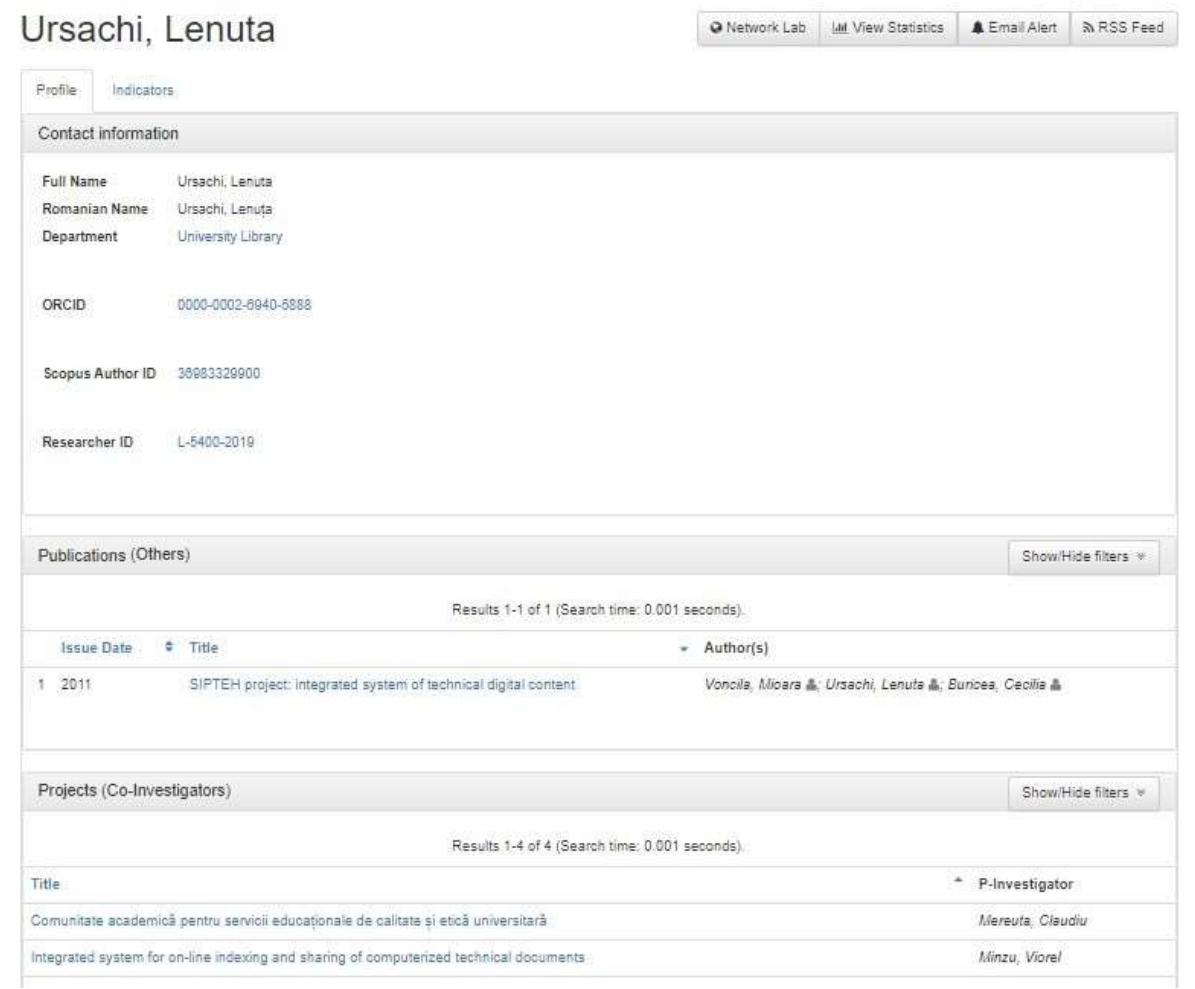

Figure 4. Researcher profile in CRIS-UGAL (ongoing project of DJUG)

An article published on the Altmetric blog reveals to readers some aspects connected to the research impact in Romania. The annual evaluation of the academics and the research trends are reflected in the number of publications and citations, number of journals included in red, yellow and grey zone (UEFISCDI classification) and h-index (Ursachi \& Huidiu 2016).

In 2015 , the RL had been approached by one of the vice-rectors to elaborate a series of working instructions in order to clarify the h-index search on three platforms: Google Scholar, Web of Science and Scopus. For a better understanding of the mechanism, three video guides were also developed by using CamStudio screenrecording software. Frequently, the RL supports academics on where to find their h-index and recommends them to sign up for services as Publons to eliminate the deficiencies detected in Web of Science author search. The library staff engaged in training sessions for the purpose of understanding bibliometrics.

In 2019, as team member in Expert project, the RL had to analyze the DJUG position in Shanghai top for the period 2015-2019. The report included definitions of the bibliometric indicators analyzed in Shanghai top, bibliometric data on Romanian universities extracted from 2015-2019 editions and a comparative analysis of the DJUG's position in relation to other Romanian universities. Conclusions drawn at the end of the document revealed the strengths and weaknesses of the institution in discussion (DJUG).

\subsection{The reference librarian as wikilibrarian}

The 1Lib1Ref campaign was an opportunity for RL to add references in Wikipedia. During the workshop "Wikimedia and librarians", organized by the National Library of Romania in 2019, librarians coming from all types of libraries were trained in wiki editing and adding images to Wikimedia. The event had a positive impact on RL from DJUG. A draft article created for DJULG included the most important elements that are specific to wiki pages: citing references, links to other wiki pages, inserting Wikimedia images, the brief information box, the Wikidata element (Fig. 5). 


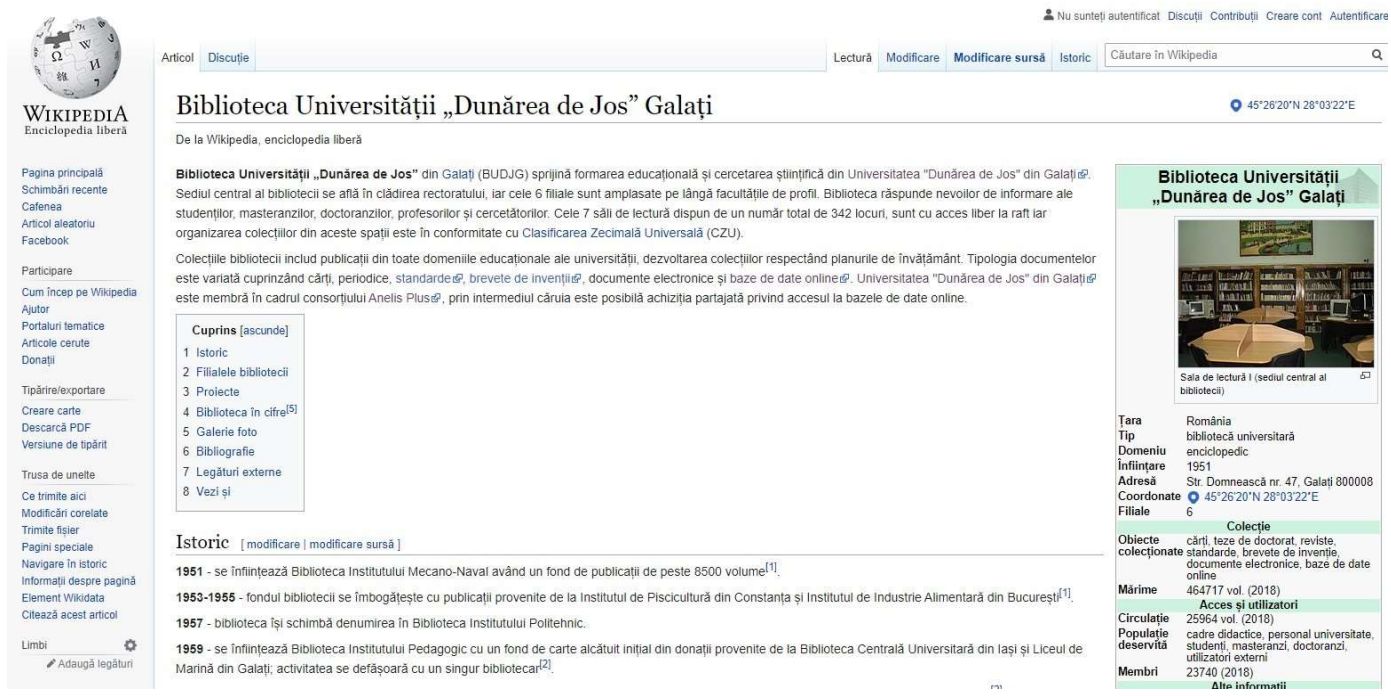

Figure 5. Wiki project of DJULG (Wikipedia 2019)

\subsection{The reference librarian and library marketing}

On a daily basis, RL is close to the users and looks for solutions to ensure the delivery of high quality products and services (Anghelescu \& Zănescu 2000 p. 37). In most of cases, the RL has been assigned to meet students in order to disseminate information about library collections and services. These meetings represent great opportunities to increase the library's visibility in the community. They are advertised on library website or Facebook page and participants received brochures or bookmarks before the event started. For the design of the marketing products, the RLs follow the AIDA model (Anghelescu \& Zănescu 2000 p. 47):

draw attention (A)

generate interest (I)

create a desire to use (D)

determine action (A).

RL exploited the digital tools provided by MS Office 2013 package or Canva for library marketing. The design combines image and text with taste, inventiveness and intelligence and the information is presented in such manner that arouses the reader's interest and desire to exploit (Ciorcan 1997 pp. 8-9). At DJULG, the RLs create and distribute marketing tools such as:

posters, to promote events organized by the library;

brochures, to offer information about collections, services and tools (Fig. 6);

bookmarks, to understand the systematic organization of library fund or the importance of reference managers;

library guides, to raise awareness of electronic resources.

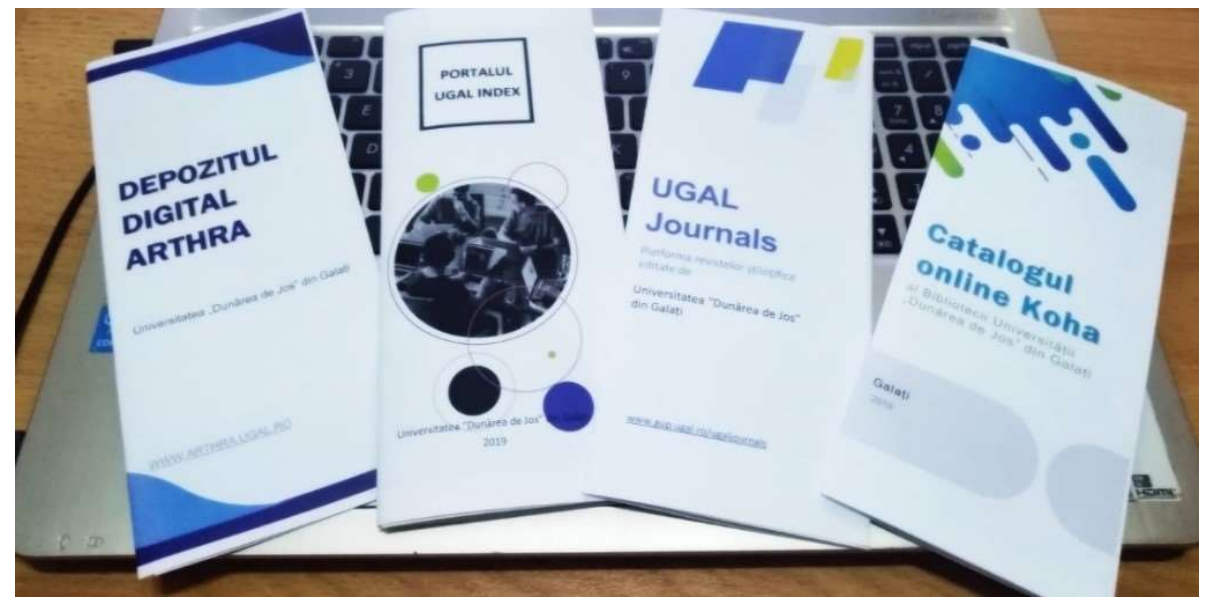

Figure 6. DJULG marketing products 


\section{Conclusions}

Information technologies have an extraordinary impact on both the user and librarian. They involve new strategies for finding and organizing information, changes in the information needs of users, with consequences on RLs and the services provided. Everyday work needs to be rethought and reinvented and some of the traditional activities should be eliminated. The RLs have to spend more time studying the trends in modern academic libraries as well as implementing new solutions aligned with the current requirements of the community served.

The RLs must not forget that the knowledge of library and information science is still essential, but, at the same time, it has to cope with the technological change. The library services are usercentered and the the RLs have to deliver proactive references. Their proficiency in digital and information literacy, constant development of personal and professional skills and discernment on what is good and efficient for the users, will integrate them more in the educational process (embedded librarians).

This study case looks over a few projects at DJULG and the redears perceive the RL as a person with high technical skills, with expertise in information retrieval and organization and software tools. The RL is able to develop and provide learning strategies to suit a particular situation which the user is facing during research process. The various cases described in this paper bring the RL in the position of quintessential mediator sitting between library and faculties (academics and students).

In conclusion, it is imperative for RLs to be continuously trained, flexible and open to new things. Consistent researches on what is relevant to the job might put some vibrant color in RL's life. Dedication to profession, willingness to help others and the continuous strive for excellence in services' delivery are the premises to elevate reference work to the rank of hobby.

\section{Acknowledgements}

I would like to express my cordial thanks to Vice-Rector, Prof. Dr. Eng. Elena Mereuță, Prof. Dr. Eng. Gabriela Elena Bahrim (former Vice-Rector), Prof. Dr. Mirela Voiculescu and Mioara Voncilă for the project experiences and to Vice-Rector, Assoc. Prof. Dr. Eng. Ciprian Vlad, Prof. Dr. Eng. Anca Ioana Nicolau (former Vice-Rector) and Prof. Dr. Florin Tudor for the opportunity to participate in seminars with students. 


\section{References}

Anghelescu, Hermina G.B. (2008) Serviciile de referință: Cheia succesului unei biblioteci, in Corghenci, L. (ed.) Dimensiuni manageriale în activitatea instituției info-bibliotecare: Concepte, experiențe, orientări, Chișinău: Universitatea Liberă Internațională din Moldova, pp. 56-60.

Anghelescu, H. and Zănescu, G. (eds) (2000) Necesitățile utilizatorilor și familiarizarea cu resursele informaționale în pragul mileniului, Timișoara: Brumar.

Biblioteca Universității "Dunărea de Jos" din Galați (2003) Regulamentul de organizare și funcționare a Bibliotecii Universității "Dunărea de Jos" din Galați, Galați: Universitatea "Dunărea de Jos" din Galaţi.

Biblioteca Universității "Dunărea de Jos" din Galați (2008) Regulamentul de organizare și funcționare a Bibliotecii Universității "Dunărea de Jos" din Galați, Galați: Universitatea "Dunărea de Jos" din Galaţi.

Biblioteca Universității "Dunărea de Jos” din Galați (2019), Wikipedia [online], available: https:// ro.wikipedia.org/wiki/Biblioteca Universit $\% \mathrm{C} 4 \% 83 \% \mathrm{C} 8 \% 9 \mathrm{Bii} \% \mathrm{E} 2 \% 80 \% 9 \mathrm{EDun} \% \mathrm{C} 4 \%$

83rea de Jos\%E2\%80\%9D Gala\%C8\%9Bi [accessed 28 August 2019 18:55].

Buluță, G., Craia, S. and Petrescu, V. (2007) Biblioteca în societatea informației, București: DoMinoR.

Coravu, R. (2012) Intermediarul difuz: biblioteca universitară între cultura tiparului și cultura digitală, Constanța: Ex Ponto.

Cox, A., Gadd, E. and Petersohn, S. (2017) Competencies for bibliometrics, Journal of Academic Librarianship, 51(3) pp. 1-17, available: https://journals.sagepub.com/doi/ pdf/10.1177/0961000617728111 [accessed 16 November 2020].

Danner, R. A. (1998) Redefining a profession, Law Library Journal, 90(3) pp. 315-356.

Gadd, E. (2017) Bibliometrics a job for the library or the research office?, SCONUL Focus 69, pp. 35-37, available: https://www.sconul.ac.uk/publication/bibliometrics-a-job-for-the-library-or-theresearch-office [accessed 16 November 2020].

Goetsch, L. A. (2008) Reinventing our work: New and emerging roles for academic librarians, Journal of Library Administration, 48(2) pp. 157-172, available: https:// doi.org/10.1080/01930820802231351 [accessed 16 November 2020].

Horvat, S. (1996) Introducere în biblioteconomie, București: Grafoart.

Ursachi, L. (2017) Activități de cultura informației desfășurate în cadrul proiectului PERFORM, in Micle, M., Lovasz, A. and Bursașiu, S. coord. Biblioteca fără bariere : Conferința Națională a Asociației Bibliotecarilor din România, Timișoara, 7-9 Septembrie 2016, Timișoara: Editura Universității de Vest ; București : Editura ABR, pp. 105-111.

Ursachi, L. (2018) The Reference Librarian Face-to-Face with Reference Management, Revista Română de Biblioteconomie și Știința Informării = Romanian Journal of Library and Information Science, 14(2) pp. 46-55, available: https://doi.org/10.26660/rrbsi.2018.14.2.46 [accessed 16 November 2020].

Ursachi, L. and Huidiu, C. (2016) Assessing the impact of research results in Romania, Altmetric Blog [online], available: https://www.altmetric.com/blog/assessing-the-impact-of-research-resultsin-romania [accessed 16 November 2020].

Ursachi, L. and Scutelnicu, E. (2012) New concepts and techniques implemented by Dunarea de Jos University Library of Galati, in Proceedings of the Third International Conference in Romania on Information Science and Information Literacy, Sibiu, April 22th - 24th 2012 [CD-ROM], Sibiu: Universitatea "Lucian Blaga" din Sibiu. 